\title{
Domingo de Soto and the Vagueness of Vagrancy: The Wickedness of Itinerant Lives
}

Beatriz E. Salamanca - UCL

\begin{abstract}
$\underline{\text { Abstract: }}$
In 1545 Domingo de Soto argued that the truly poor, whether or not they were in their native land or in a foreign one, had freedom of movement to beg from door to door and from one city to another, as long as they were true paupers and their mobility did not acquire the taint of vagrancy. This right to free movement was meant to be valid both internally and abroad, thus challenging the power of the commonwealth over its own borders. This article will examine the political significance of Soto's idea of free movement and explore the question of whether vagabonds were so straightforwardly excluded from the freedom of movement that he attributed to the truly poor. The controversial nature of this discussion demonstrates how difficult it was and still is to address the issue of the circulation of peoples across frontiers, and challenges the interplay of categories such as 'Belonging' and 'Transgression'.
\end{abstract}

$\underline{\text { Keywords: }}$

Domingo de Soto, Vagrancy, Freedom of Movement, Borders, Spanish Monarchy

DOI:

$10.14324 / 111.2057-2212.070$

Introduction:

In 1545 the Spanish Dominican Domingo de Soto wrote his Deliberation on the Cause of the Poor as a response to the Poor Law of 1540, which had ordered the local deserving poor to obtain licences to beg, and had prescribed the expulsion of foreign paupers. The growing number of paupers arriving in urban centres and seeking relief implied that one of the main targets was to identify those who truly deserved aid. The distinction between true paupers and vagabonds was of enormous significance for a historical period so keen on suppressing vagrancy while at the same time relieving poverty. For Soto, the truly poor, whether or not they were in their native land or in a foreign one, had freedom of movement to beg from door to door and from one city to another, as long as they were true paupers and their mobility did not acquire the taint of vagrancy. In his own words:

No one may be expelled from any place unless he has committed an offense or crime (...) And the reason for this is that by natural law and the law of nations, everyone has the 
freedom to move wherever they wish, as long as they are not enemies or causing harm; and even though expelling someone from a city and sending him back to his native land is not formally exile, he would be being deprived of his right, which cannot be taken away from him unless an offense is committed. As a result, the true pauper who begs in the name of God is committing no crime or offence, and therefore cannot be expelled from any place (Soto, 2003: 64). ${ }^{\mathrm{i}}$

In this paper I intend to explore the question of whether vagabonds were so straightforwardly excluded from the freedom of movement that Soto attributed to the truly poor. The answer to this question is not easy, as Soto's approach to vagrancy was not entirely consistent, sometimes seemingly justifying the situation of vagrants, and at others declaring that they should be punished. I will argue, though, that these contradictions demonstrate that the distinction between the truly poor and the vagrant was more problematic than has usually been assumed. Although the question of whether or not Soto favoured the closing of borders to vagabonds cannot be answered with complete certainty, there is some previously overlooked evidence which seems to suggest that he believed that it was preferable to allow them free mobility. Contrary to Annabel Brett's interpretation (2011:25), I consider that Soto's approach to vagrancy was not completely typical, and was, in fact, ambiguous enough to highlight the problematic dimension behind the attempt to implement a programme of mobility regulation based on an undefined and blurred notion of vagrancy. Here I will concentrate on Soto's references to the wickedness associated to vagabonds, as it is one of the aspects which more strongly reflects the vagueness of the term itself.

As Soto himself tried to define them, vagabonds lacked a home of their own and moved about wandering through the world with no evident purpose. The perpetual motion of their lives was not motivated by necessity or utility. In Soto's initial portrayal this meant that vagabonds were neither true paupers, nor travellers with a trade or occupation. Instead, they were idle and masterless men, equivalent to 'unproductive land, or cattle with no owner' (Soto, 2003: 57).

Soto insisted on the shared belief that vagabonds had to be punished, and, as he explained, this was not a novelty, since there were precedents in the ancient laws of the kingdom, and in divine and natural law (57). As Soto recounts, vagrants had historically been condemned to either exclusion or forced labour, as had previously been contemplated in the Code of Justinian of 529-534 and the Siete Partidas of 1256-1265, or to one month of unpaid work according to the later Spanish Law of Birviesca of 1387.

About 70 years later, Sebastián de Covarrubias's Tesoro de la lengua castellana still addressed many of the common places about what it meant to be a vagabond. In his own words: 'to go idly from one place to another, the verb vacare (...) In this kingdom there are laws against vagamundos, and all well-organized republics have these laws, because these people are harmful and if they have no food will steal it, and this is why Draco, in his blood-thirsty laws, imposed the death penalty on them' (Covarrubias, 1611: 78). In a way, anti-vagrancy laws sought to criminalize the poor, not only because of their 'idleness', but also because of their itinerant behaviour and their condition as foreigners or outsiders. In early modern Spain, those who belonged to another village or city were considered as 
foreign as those who came from other nations. Vagrancy was not related to travellers with a trade or occupation, nor idle aristocrats, but wandering strangers in a condition of poverty. The burden of being foreign was indeed carried by those with no means, something that the prominent Spanish Baroque poet Francisco de Quevedo had already noticed by remarking, 'among all nations, only the poor person is a foreigner' (Quevedo, 1788: 175-176). Like vagabonds, foreigners were often associated with a mischievous behaviour, and there are some examples of French male migrants who were highly distrusted because of their promiscuous sexual activities (Behrend-Martínez, 2015: 579-594).

Likewise, many foreign seasonal workers were seen as indistinguishable from vagabonds. The testimony of the economist Pedro Fernández Navarrete in the 1620s is a case in point, as he complained in his Conservación de monarquías y discursos politicos that 'all the scum of Europe have come to Spain so that there is hardly a deaf, dumb, lame or blind man in France, Germany, Italy or Flanders, who has not been to Castile' (Navarrete, 1805: 57). ${ }^{\text {ii }}$ Pilgrimages were another context in which large numbers of people moved across regions, and the route from France to Santiago de Compostela was one of the most famous ones. For some pilgrims it was not uncommon to overstay in Spanish territory, encouraged by the well known hospitality they received along the route. In effect, among the masses moving towards Santiago there were also the so called 'charlatan pilgrims', who would dress up as pilgrims and wear the cockleshell emblem normally picked up on the beach at the end of the journey as proof of having been to Compostela (Krausse, 1999: 55). This is probably the reason why the Poor Law of 1540 forbade pilgrims from leaving the route beyond four miles and Philip II forbade pilgrim attire in 1590, forcing the faithful to carry an identity document issued by the local authorities giving the person name, age, destination, and 'distinguishing' marks (Groebner, 2007: 209-10). Pilgrims began being linked to vagrants and this perception was present in Sebastián Covarrubias's definition of the word vagar, or to wander, which placed the very origin of the word 'vagabond' on pilgrims coming to Spain from France. As he put it, 'en tiempos atrás acudieron muchos de una ciudad de Francia, dicha Bagamun, que hoy llamamos Tornay, y de allí se dijeron vagamundos' (a long time ago many came from a city in France called Bagamun, known today as Tornay, and it was then that the word 'vagamundos' came into being) (Covarrubias, 1611: 78).

Even though Soto quotes these legal precedents, there is straightforward evidence that he breaks from traditional attitudes towards vagrancy. As he observed, these previous legal accounts made reference to what had so far been considered as licit in relation to vagrancy, but the convenience of such measures had to be separately addressed. Making reference to Paul, he added: 'many things are licit which are not expedient nor edifying, and for which the opposite would be better (...) And between two similarly licit things, the most convenient should be determined by the rules of equity and prudence' (Soto, 2003: 57). Soto does not go any further on this idea but he was certainly open to discuss the condition of vagabonds beyond its legal framework, and in terms of equity.

In this way, one of the elements Soto explores is the connection between vagrancy and delinquency. As he notes it, the very origin of this association comes from the widespread assumption that idleness easily turned into wickedness. Making reference to Plato and Aristotle, Seneca and Cicero, and Saint Augustine, he describes a common attitude against those with no excuse for their idleness, which inevitably leads to wickedness: 'the idle 
person is always impregnated with desire, and that is why he can only give birth to evil' (Soto, 58). This was linked to a shared believe, present in both the catholic and protestant world, which repudiated idleness and praised work. A popular passage from the scriptures quoted by both Soto and the Spanish humanist Juan Luis Vives advised, 'if any would not work, neither should he eat' (Soto, 58; Vives, 1997: 30). As part of Vives' defence of the state's involvement in poor relief programmes, he would insist that 'no one should be allowed to live idly in the city, where, like in a well-organized house, everyone must fulfil their duty' (Vives, 28). This praise of 'work' was particularly present in Lutheran manifestations, and artist like Lucas Cranach would venture to depict the connection between female idleness and wickedness, for instance, in his Allegory of Melancholy of 1528, where he depicts a young woman, indifferent to the world which surrounds her, submersed in the state of idleness that come with melancholy, evoking a cloud of sinful scenes and demonic behaviour.

Although Soto does not really question the link between idleness and wickedness, he definitely argues against framing all vagrants as evil delinquents. According to the Dominican, the harsher the measures, the more likely it was that vagabonds turned into thieves, thus granting that not all vagabonds were effectively thieves (Soto, 88). In these terms, the punishment of those vagabonds that committed an offense was in the hands of those in charge of dispensing justice, and not a matter of concern in the context of the discussion of poor relief (Soto, 91). In any case, Cervantes' heroic and legendary character Don Quixote, a vivid example of a wandering life with no known purpose or direction, echoed the ambiguity imbedded in the figure of the vagrant. The knight-errant, who sought to bring about justice and followed the path his horse Rocinante wanted to go, was not exempted from criminal accusations and from being identified as a fugitive of justice (Echevarría, 2005: 61).

The connection between vagrancy and delinquency was also present in Soto's more well known work On Justice and Right of 1556 where he mentioned the existence of errant people who moved about causing harm. As Soto wrote:

As Aristotle claimed, in the first book of his Politics, chapter 3, in the same way as a beast can be sold, war can be waged against those who were born to serve, meaning that we can use force to drive back and bring to order those who, like wild beasts, wander around with no respect for the laws of the pact, invading people's property wherever they go (19671968, lib. IV, q. 2, a. 2).

According to Annabel Brett's interpretation of this fragment, to a certain extent Soto compares vagabonds to the Aristotelian category of natural slaves, against whom a just war could be waged (Brett, 2011:26). However, I consider that a closer look to this passage may lead to a different perspective. In the first place, the use of the word repeler or 'drive back' seems to suggest that the war mentioned by Soto is actually a response to an act of aggression. His allusion to the use of force seems to be more in tune with a defensive attitude rather than a justification of war based on natural slavery. Soto is not targeting vagabonds or itinerant people as such, but itinerant people who roam around breaking the law, stealing and causing harm. In effect, the notion of natural slavery had already been challenged by the Dominicans, and the concept of servus, which is the Latin word used in 
the text, was often employed in the sixteenth century more closely to the medieval serf, or to the notion of servidumbre, than the slave in Aristotle's mind, as was pointed out by Robert E. Quirk in relation to Juan Ginés de Sepulveda's debate with Bartolomé de las Casas regarding the Indians of the New World (Quirk, 1954: 358).

To Soto, society overreacts to the wickedness of vagabonds and pays no attention to its own faults. In his own words, 'in all states, among officers, among men of letters and public ministers, among clerics and friars, grandees and prelates, they all have differing degrees of weakness, sin and wickedness' (Soto, 87). According to Soto, the lack of virtuousness of the poor should not be constantly brought to trial, in the same way that the faults of the rich were not a matter of routine punishment. This idea that not all human vices ought to be regulated by law can be linked to the doctrine of Thomas Aquinas, a central figure for the members of the School of Salamanca and a greatly influential figure for the scholastic approach to knowledge who Soto so closely followed. To Aquinas, the majority of men are not close to perfect virtue, and for this reason:

human law does not prohibit all the vices from which virtuous men abstain, but only the more grievous ones, from which it is possible for the greater part of the community to abstain; and especially those which do harm to others, without the prohibition of which, human society could not be maintained. Thus human law forbids homicide, theft and things of that kind (Aquinas, 2002: 240).

Soto certainly agreed with Aquinas' precept, as he added that 'if all sins in this world were punished, there would be no sin left for god to punish after the judgement' (Soto, 87).

The wickedness attributed to the wandering poor took place in different contexts. Another form of wicked behaviour was attributed to fraudulent beggars or those who fabricated their own wounds and dissimulated disabilities. To Soto, though, this was only an argument of the rich to excuse their greed and lack of charity. He supported his view with the writings of John Chrysostom, who had argued that the needs of the poor had to be of enormous dimensions so as to go through the trouble to appear infirm or weakened, and the cruelty and lack of mercy of the rich were to be blamed for the deceitful attitude of the poor, whose cries where never enough to move them to pity. In this way, Soto concluded that: "if we gave way to feelings of pity for the poor more easily, they would not need to resort to these arts. (...) There are some who remove the eyes of their own children in order to penetrate our insensible hearts' (Soto, 86).

Soto's moderation towards vagabonds and fraudulent beggars is incredibly surprising, considering that this was likely to be one of the most repudiated practices of the time. Juan de Robles condemned it in his own treaty, and used it as one of the main justifications for implementing a more centralized programme of poor relief, as he believed that the tricks that were played on individualized charity would not take place against an organized system. As Robles put it: 'In no case is it right but always wrong that by cheating we move others to give up part of their wealth (...) It is better to give less alms properly, than more plentiful alms in a disorganized way and into the hands of people who cause harm to the republic' (Robles, 2003: 166). 
In contrast to Soto's permissive attitude, in the vocabulary of the time the fraudulent poor were pretty much equivalent to vagrants. Following the first publication of the Liber Vagatorum, about the year 1512-1514 in Germany, some similar books were edited in England afterwards (Camden, 1860: xxiv). In the Liber Vagatorum there are references to many of the false arguments employed by vagabonds, like the ones who claimed to be liberated prisoners, cripples, church mendicants, learned beggars or young scholars or students, 'strollers', pilgrims, blind beggars, naked beggars, demoniacs, hangmen, pregnant women, noblemen and knights, and merchants who had been robbed, among many others (1860, 11-38). Martin Luther, who wrote the preface and corrected some of the passages to the 1528 edition of this book, placed mendicant orders under the category of the undeserving poor, arguing that giving them alms was as bad as given alms to vagabonds: 'whereas people will not give and help honest paupers and needy neighbours, as ordained by God, they give, by the persuasion of the devil, and contrary to god's judgement, ten times as much to Vagabonds and desperate rogues, -in like manner as we have hitherto done to monasteries, cloisters, churches, chapels, and mendicant friars, forsaking all the time the truly poor'(Luther, 1860: 4).

In short, Soto shows no sympathy for vagabonds, yet he is not entirely persuaded that the best solution is to expel them. He claims that, given the case, vagabonds who commit offenses should be punished by those who are ordinarily in charge of dispensing justice, but he refrains from assuming that these early modern infamous wanderers were inherently wicked. It could be asked then, what was it about early modern Spain that wandering was made such an important theme? What was it about itinerant behaviour that made the authorities so uncomfortable, and carried so many negative connotations? Women on the road, 'away from their homes and from the protective legal custody of fathers and brothers' were automatically seen as prostitutes and it was precisely their wandering ways which were seen as a form of depravity (Echevarría, 2005: 61).

Domingo de Soto's observations on vagrancy were published less than a decade before Philip II implemented harsher measures in 1552, when vagabonds began being sent to the galleys from four to eight years or for life, depending on whether they relapsed. ${ }^{\text {iii }}$ It also took place before the Spanish literary world linked wandering behaviour with the figure of the pícaro. In this way, Soto's more open and tolerant attitude towards vagabonds may not have been so influential in terms of public policy, but it seems to have inspired the need to look further into the meaning and the political significance of the perpetual motion of these lives.

\section{$\underline{\text { Works Cited }}$}

\section{Primary Sources}

Aquinas, Thomas. 'Summa Theologiae' in Political Writings, R. W. Dyson. Cambridge University Press, 2002. Print.

Camden Hotten, John. 'Introduction' in The Book of Vagabonds and Beggars: with a vocabulary of their Language. Ed. Martin Luther. London: John Camden Hotte, 1860. 
Print.

Covarrubias, Sebastian de. Tesoro de la lengua castellana o Española. Madrid: Luis Sanchez, impresor del rey, 1611. Print.

Luther, Martin. 'Preface' in The Book of Vagabonds and Beggars: with a Vocabulary of their Language. Ed. Martin Luther. London: John Camden Hotte, 1860. Print.

Navarrete, Pedro Fernández. Conservación de monarquías y discursos políticos sobre la gran consulta que el consejo hizo al señor rey don Felipe Tercero. Madrid, imprenta de don Tomas Alban, 1805. Print.

Novísima recopilacion de las leyes de España. Dividida en XII libros, en que se reforma la recopilacion publicada por el señor don Felipe II. En el año de 1567. Madrid, 1805. Print.

Quevedo, Francisco de. 'Cartas del caballero de la tenaza' in Obras escogidas de D. Francisco de Quevedo Villegas, tomo II. Madrid: imprenta de Gonzales, 1788. Print.

Robles, Juan de. 'De la orden que en algunos pueblos de España se ha puesto en la limosna, para remedio de los verdaderos pobres' in El gran debate sobre los pobres en el siglo XVI. ed. by Félix Santolaria Sierra. Barcelona: Ariel, 2003. Print.

Soto, Domingo de. De iustitia et iure, De la justicia y del derecho. Madrid: Instituto de Estudios Políticos, 1967-1968. Print.

—, Deliberación en la causa de los pobres', in El gran debate sobre los pobres en el siglo XVI. ed. by Félix Santolaria Sierra. Barcelona: Ariel, 2003. Print.

The Book of Vagabonds and Beggars: with a vocabulary of their Language. Ed. Martin Luther. London: John Camden Hotte, 1860. Print.

Vives, Juan Luis. El socorro de los pobres: la comunicación de bienes. Tecnos, 1997. Print.

Secondary Sources

Behrend-Martínez, Edward. 'Spain Violated: Foreign Men in Spain's Heartland'. European Review of History: Revue européenne d'histoire, 22:4, (2015) 579-594. Print.

Brett, Annabel S. Changes of State: Nature and the Limits of the City in Early Modern Natural Law. Princeton University Press, 2011. Print.

Echevarría, Roberto Gonzalez. Love and the Law in Cervantes. Yale University Press, 2005. Print.

Groebner, Valentin. Who Are You?: Identification, Deception, and Surveillance in Early Modern Europe. Zone Books, 2007. Print.

Krause, Virginia. 'Idle Works in Rabelais' Quart Livre: The Case of the Gastrolatres'. Sixteenth Century Journal, 30 (1999), 47-60. Print.

Kamen, Henry. Early Modern European Society. Routledge, 2005. Print.

Quirk, Robert. 'Some Notes on a Controversial Controversy: Juan Gines de Supuilveda and Natural Servitude'. The Hispanic American Historical Review 34 (1954), 357-64. Print. 
Biography:

Beatriz Salamanca is a third year PhD student at the Department of Spanish and Latin American Studies at UCL, where she also did her MA in the History of Political Thought. Before joining the PhD, she worked as a teaching assistant in the Department of Law and Political Science at Javeriana University in Colombia.

(C) 2017, The Author(s). This is an Open Access article distributed under the terms of the Creative Commons Attribution License (CC-BY) 4.0 https://creativecommons.org/licenses/by/4.0/ which permits unrestricted use, distribution, and reproduction in any medium, provided the original author and source are credited.

\section{$\underline{\text { Endnotes }}$}

${ }^{\mathrm{i}}$ Unless otherwise stated, all translations into English are mine.

ii This translation is from Kamen, 2005: 186.

iii This and many other regualations on this regard are included in the Novísima Recopilación, volume V, book XII, section 31, law IV, p. 431. 